Hemiaster Cotteaui, Wright, 3 .

H. Scillæ, Wr., 1, 2, 3 .

H. vadosus, Greg., 1, 2, 3 .

Pericosmus latus, Agassiz, 2.

P. coranguimum, Greg., 3 .

Schizaster Parkinsoni, Defr., 1, 2, 3.

S. Desori, Wr., 2, 3,

Metalia Melitensis, Greg., 2.
Brissopis crescenticus, Wr., 3.

Spatangus pustulosus, Wr., 3 .

Fuspatangus De Konincki, Yr., 3.

Sarsella Duncani, Greg., 2, 3.

S. anterolata, Greg., 2, 3.

Pygorhynchus Spratti, Wr., 2.

Scutella striatula, Greg., 1.

Brissus latus, 3.

Crinoidea-Pentacrinus Gastaldi, Mich., 1, 2.

Atcronaria: Gorgonide-

Isis Peloritana, Seg., 1, 3.

I. compressa, Seg., 3.

\section{Actisozon-}

Ceratrochus typns, Seg., 2, 3.

Coenocyathus Adamsi, Duncan, 3.

Stephanocvathus, sp., $1,2,3$.

Caryophyllia, 1, 3 .

Trochocyathus latero-cristatus, $\mathrm{Edw}$.

\& H., 1, 2, 3.

T. pyramidatus, Mich., 1, 3 ,
Isis Melitensis, Seg., 3. var. antiqua, Seg., 3.

Spongrda-Cliona (perforating shells of Lamellibranchs).

Foraminifera-In addition to the 54 species recorded by Dr. Joln Murray, I have collected--

Nodosaria soluta, Reuss, 2, 3.

N. consobrina, d'Orb., 3.

Textularia carinata, d'Orb., 3 .

Cristellaria cassis, F. \& M., 3 .

C. radiata, Born., 2, 3 .
Cristellaria variabilis, Renss, 3 .

Marginulina Bœhmi, Reuss, 1, 2.

Frondicularia interrupta, Karrer, 3.

Miliolina agglutinans, d Orb., 3 .

Heterostegina Stricklandi, Adams, 1.

\title{
INOTICES OF MFMIOIRS.
}

British Association for the Advancement of Science. Sixtysixth Annual Meeting, beld at Liverpool, September 16-28, 1896.

\section{I.-List of Papigrs Read in Section (C), Geology.}

J. E. Marr, Esq., M.A., F.R.S., Sec. Geol. Soc., President.

President's Address (seo October Number, p. 464).

Prof. W. Boyd-Dawkins.-On the Geology of the Isle of Man.

H. C. Beasley.-Observations on some Footprints from the Trias in the Neighbourhood of Liverpool.

G. H. Morton-Recent Borings in the Red Marl near Liverpool (see p. 496).

G. H. Morton-Erosion of the Sea-coast of Wirral (see p. 516).

T. Mellard Reade-Oscillations in the Level of the Land as shown by the Buried River-Valleys and Later Deposits in the Neighbourhood of Liverpool (see p. 488).

A. Bell.--Tertiary Deposits in North Manxland. 
E. Greenly -On the occurrence of Sillimanite Gneisses in Central Anglesey (see p. 494).

E. Greenly-On the Quartzite Lenticles in the Schists of S.E. Anglesey.

Sir W. Dawson. - Pre-Cambrian Fossils-especially in Canada (see p. 513).

G. F. Mathew-Some Features of the early Cambrian Faunas.

Report of the Committee on Zones in British Carboniferous Rocks.

G. H. Morton.-The Range of Species in the Carboniferous Limestone of North Wales.

$J$ J. L. Lobley-On the Source of Lava.

J. L. Lobley.-On the Post-Cambrian Shrinkage of the Globe.

P. F. Kendall.-Cause of the Bathymetric Limit of Pteropod Ooze.

P. F. Kendall.-On the Conditions under which the Upper Chalk was deposited.

J. Johnston-Lavis.-The Highwood Mountains of Montana and Magmatic Differentiation. A Criticism.

G. B. Wethered.-The Depths of the Sea in Past Epochs.

Vaughan Cornish.-Rippling of Sand by Water and Wind (see p. 521).

Prof. J. Walther.-Are there Fossil Deserts?

W. W. Watts. - Notes on the Geology of Charn wood Forest (see p. 485).

F. T. Howard and E. W. Small.-The Geology of Skomer Island.

H. B. Woodward.-Notes on Sections along the London Extension of the Manchester, Sheffield, and Lincoln Railway between Rugby and Aylesbury.

Report of the Committee on Stonesfield Slate (see p. 517).

Report of the Committee on Coral-Reef Structure.

Report of the Geological Photographic Committee.

Report of the Hoxne Excavation Committee.

John Smith.--On the Discovery of Marine Shells in the Drift Series at High Levels in Ayrshire.

Dr. C. Callaway--Notes on the Superficial Deposits of North Shropshire (see p. 482).

J. Lomas and P. F. Kendall.-Glacial Phenomena of Vale of Clwyd.

P. F. Kendall.-Post-Pliocene Changes of Physical Geography.

Report of the Erratic Blocks Committee.

Prof. E. Hull.-Another Possible Cause of the Glacial Epoch (see p. 514).

Report of the Committee on the High-level Shell-bearing Deposits at Clava.

Report of the Singapore Caves Committee.

Report of the Calf-Hole Cave Committee.

Report of the Committee on the High-level Flint Drift at Ightham.

Report of the Cetiosaurus Committee.

Report of the Eurypterid Committee.

Report of the Committee on the Fossil Phyllopoda.

Report of the Committee on Life-zones in Carboniferous Rocks (see p. 519).

A. C. Seward-A New Cycad, from Portland (see p. 518).

A. C. Seward-A Large Specimen of Lyginodendron (see p. 518). 
Report of the Committee on the Registration of Type Specimens. Montagu Browne. - The Rhætic Bone-beds of Aust Cliff and the Rock-bed above it.

Prof. H. G. Seeley.-On the Skull of the South African Fossil Reptile Diademodon.

Prof. H. G. Seeley.--'Two examples of Current Bedding in Clay.

Sir Archibald Geitie.-On some Crush-Conglomerates in Anglesey (see p. 481).

Prof. J. Milne.-Report of the Seismological Committee.

A. C. Seward.-Note on some Fossil Plants from South Africa (see p. 519).

Prof. K. Busz.-On the occurrence of Corundum produced by Contact-metamorphism (see p. 492).

Report of the Moreseat Committee.

Abstracts of Papers read at the British Association Meeting, Liverpool, September, 1896.

II.-Pre-Cambrian Fossils. By Sir W. Dawson, LL.D., F.R.S. 1 IHE author stated that it was bis object merely to introduce the specimens he proposed to exhibit by a few remarks rendered necessary by the present confusion in the classification of preCambrian rocks. He would take those of Canada and Newfoundland as at present best known, and locally connected with the specimens in question.

He referred first to the "Olenellus Zone," and its equivalent in New Brunswick, the "Protolenus Fauna" of Matthew, as at present constituting the base of the Cambrian, and terminating downward in barren sandstone. This Lower Cambrian had in North America, according to Witcott, afforded 165 species, including all the leading types of the marine invertebrates.

Below the Olenellus Zone, Matthew had found in New Brunswick a thick series of red and greenish slates, with conglomerate at the base. It has afforded no Trilobites, but contains a few fossils referable with some doubt to Worms, Mollusks, Ostracods, Brachiopods, Cytideans, and Protozoa. It is regarded as equivalent to the Signal Hill and Random Sound Series of Murray and Howley in Newfoundland, and to the Keweenian, and the Chuar and Colorado Cañon Series of Walcott in the west. The latter contains laminated forms apparently similar to Cryptozoon of the Cambrian and Archæozoon of the Upper Laurentian.

The Etcheminian rests unconformably on the Huronian, a system for the most part of coarse clastic rocks with some igneous beds, but including slates, iron-ores, and limestones, which contain wormburrows, sponge-spicules, and laminated forms comparable with Cryptozoon and Eozoon. The Iuronian, first defined by Logan and Murray in the Georgian Bay of Lake Huron, has been recognized in many localities, both in the west and east of Canada and the United States; but designated by other Jocal names, and by some writers is included, with the Etcheminian and sometimes with 


\section{Notices of Memoirs-Prof. E. Hull-Glacial Epoch.}

part of the Laurentian, in the scarcely-defined "Algonkian" group of the United States Geological Survey.

Below the Huronian is the Upper Laurentian or Grenville system, consisting of gneisses and schists (some of which, as Adams has shown, have the chemical composition of Palæozoic slates), along with iron-ore, graphite, and apatite, and great bands of limestone, the whole evidently representing a long period of marine deposition, in an ocean whose bed was broken up and in part elevated before the production of the littoral clastics of the Huronian age. It is in one of the limestones of this system that, along with other possible fossils, the forms known as Eozoon Canadense have been found. The author did not propose to describe these remains, but merely to exhibit some microphotographs and slices illustrating their structure, referring to previous publications for details as to their characters and mode of occurrence.

Below the Grenvillian is the great thickness of orthoclase gneiss of various textures, and alternating with bands of hornblende schist, constituting the Ottawa gneiss or Lower Laurentian of the Geological Survey. No limestones or indications of fossil remains have yet been found in this fundamental gneiss, which may be a truly primitive rock produced by aqueo-igneous or "crenitic" action, before the commencement of regular sedimentation.

The author proposed, with Matthew, to regard the Etcheminian series and its equivalents as pre-Cambrian, but still Palæozoic; and, as suggested by himself many years ago, to classify the Huronian and Grenvillian as Eozoic, leaving the term Archæan to be applied to the Lower Laurentian gneiss, until it also shall have afforded some indications of the presence of life.

$\mathrm{He}$ insisted on the duty of palæontologists to give more attention to the pre-Cambrian rocks, in the hope of discovering connecting links with the Cambrian, and of finding the oceanic members of the Huronian, and less metamorphosed equivalents of the Upper Laurentian, and so of reaching backward to the actual beginning of life on our planet, should this prove to be attainable.

IIJ.-Another Possible Cause of the Glacial Epoch. By Professor Evward Hull, LL.D., F.R.S., F.G.S.

1 THE author gave an account of the results arrived at by Professor J. W. Spencer, Ph.D., in his memoir on "The Reconstruction of the Antillæan Continent" (Bull. Geol. Soc. America, January, 1895), from observations laid down on the Admiralty charts of the east coast of North America and the shores of the West Indian Islands and Gulf of Mexico. He shows that the "continental shelf" lying between the coast and the 100 -fathom line is succeded by a second and deeper plateau, called by Professor A. Agassiz "the Blake plateau," the averagre depth of which may be taken at 2,700 feet, separated from the continental shelf by a steep descent, and in its turn bounded by a second steep descent leading down to the abysmal depths of the Atlantic Ocean at 12,000 or 13,000 leet 
below the surface. A careful investigation of the soundings shows that these plateaux are traversed by channels, sometimes of great depth and with precipitous sides, leading down from the embonchures of the existing rivers which open out on the coast, and connected with the outer margins of the plateaux by wide embayments. The form of these channels would in some cases entitle them to be called "cañons" or "fjords"; and as Professor Spencer truly considers that such channels could only be formed by river erosion, he concludes that the whole eastern coast and the West Indian Isles were elevated to the extent of the outer embayments where they open out on the floor of the ocean. Such an elevation of 12,000 feet or so would have connected North and South America along the line of the Antilles, constituting a single continent, and are termed "stupendous changes of level " of the Pleistocene epoch."

The author of this paper proceeds to discuss some of the climatic conditions which would result from such changes, and supposes that the elevation of the Antillæan continent would have shut out the northern branch of the great equatorial current, known as the Gulf Stream, from the Caribbean Sea and the Gulf of Mexico, causing it to enter the North Atlantic directly; and he comes to the conclusion that the Atlantic current would have crossed the 40th parallel with a surface temperature of only $74^{\circ} \mathrm{F}$. instead of $84^{\circ} \mathrm{F}$., as is the case at the present day. The author then discusses the question to what extent such a lowering of the temperature of the present Gulf Stream would have affected the climate of the regions bordering the North Atlantic, and considers that this effect may be approximately arrived at by transferring the climatio conditions of the isotherm of annual mean temperature of $32^{\circ} \mathrm{F}$. (the freezing-point of water) to those of the $42^{\circ} \mathrm{F}$. of the present day, resulting in subglacial conditions along the line of this isotherm. ${ }^{2}$

Proceeding next to examine the effects of the elevation of the American continent to the extent required by Professor Spencer's conclusions, the anthor considers it as extremely probable that the cold produced by this physical change, added to that due to the lowering of the temperature of the Atlantic current, would result in bringing about the conditions of the Glacial epoch; and as similar elevation of land has been determined in the case of the platform of the British Isles and North-Western Europe-though to a much smaller extent than in the case of the American continent-the increased cold due to this cause, added to that due to the diminished temperature of the Atlantic current, would bave been, if not a vera causa of the Glacial epoch of Europe, a most material cause in bringing about the climatic conditions of that epoch.

1 For those who are unable to obtain Professor Spencer's original memoir, the review thereof by Mr. A. J. Jukes-Browne, F.G.S., in the Geological Magazine for April, 1895 (p. 173), will probably suffice.

2 The isotherm of $42^{\circ}$ passes by the north coast of the British Isles. 


\section{Notices of Memoirs-G. H. Morton-Erosion of Wirral.}

\section{IV.-Erosion of the Sha-coast of Wirral. By G. H. Morton, F.G.S.}

I IHE oldest maps of the coast of Wirral, the north-western extremity of Cheshire, afford very little information on the exact outline of the coast in former years. It was not until the publication of the 6-inch map of the Ordnance Survey in 1880 , that it became possible to make exact observations on the erosion of the coast. The late Sir James Picton, F.S.A., in 1846, was the first to direct attention to the waste of the land, but he had not made any personal investigation, and more recent writers on the subject have confined themselves to showing the incorrectness of some of his statements, rather than making original observations. The object of this paper is to record the result of close attention given to the subject for many years.

Half a mile south-west of the Leasowe Embankment, and abont 100 yards from Seabank Cottages, there is an old weather-beaten brick and stone house, known as the "Warren," and evidently the oldest in the neighbourhood. According to the 6-inch Ordnance Map, the distance between the house and the sea was abont 130 yards when the country was surveyed in 1871 , but I found it to be 70 yards in 1890,55 yards in March 1894, and only 45 yards in May 1896, and the residents have shown me the position of several high sand-hills that once formed part of the lost land.

In an affidavit, filed in a recent case concerning the extension of the Embankment, George Banks states that he had been born and had lived in the house ever since. It was only 60 yards from highwater mark at spring tides in 1892, "whereas when he first remembered it, the house stood at least 350 yards from high-water mark at spring tides, and the land washed away included some sand-hills 30 and 40 feet, and one 50 or 60 feet in height."

The greatest erosion by the sea along the coast has taken place at Dove Point, about 350 yards to the south-west of the house. In 1862 there were two "perches" constructed of timber, one being 10 yards from the edge of the sand-hills, which were then about 12 feet high, and the other 150 yards behind, near the boundary of the enclosed land. The seaward perch is shown in the frontispiece of the "Geology around Liverpool." On January 20, 1863, this perch had become close to the edge of the cliff and tell down on the shore, its original position being indicated by several masses of masonry and large stones wbich had formed the foundation of the structure. The perch was re-erected on the sand-hills, and is shown on the 6-inch map, but it was afterwards removed, with the one behind, to the north-east of the "Warren," so that neither of them is now in the place shown on the map. The foundation stones still lie on the shore in their original position. In consequence of the continual erosion by the sea the stones have gradually become furtber from the coast-line, and in September, 1894, the distance was 144 yards, showing the erosion of the coast from 1863 to 1894 to have been between 4 and 5 yards per annum. In May, 1896, the 
ristance had been increased to 152 yards, proving an erosion of 8 yards in 20 months, but as they included two winters the loss would be about 4 yards per annum.

South of Dove Point the erosion gradually decreases, but 50 yards of the sand-hills have been washed away on the north-east of Sandhey, though not in recent years, as there is now a fringe of grass growing in the denuded bay for about 100 yards, when it gradually dies away. The grounds along the sea-front at Sandhey are protected by an embankment and groins, which arrest the encroachuent of the sea. Beyond, in front of Hoylake, there is no erosion, and the Red Stones at Hilbre Point protect the land from the sea.

V.-Stonesfield State.-Third and Final Report of the Committee, consisting of H. B. Woodward (Chairman), E. A. Walford, F.G.S. (Secretary), Professor A. H. Green, Dr. H. Woopward, and J. WINDoEs, appointed to open further sections in the neighbourhood of Stonesfield in order to show the relationship of the Stonesfield Slate to the underlying and overlying strata. (Drawn up by Edwin A. Walfokd, F.G.S., Secretary.)

$7 \mathrm{HE}$ succession from the Great Oolite through the Stonesfield 1 Slate into the Inferior Oolite, as shown in the sections made by your Committee, may be thus summarized :-

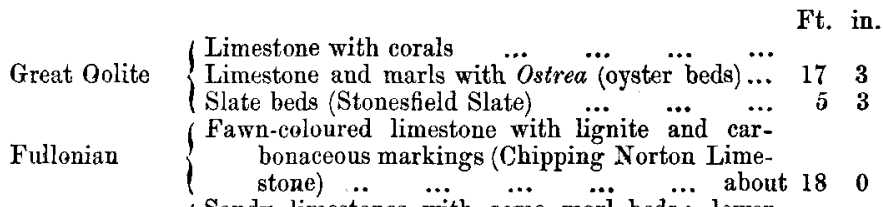

$$
\begin{aligned}
& \begin{array}{c}
\text { Inferior Oolite } \\
\text { Series }
\end{array}\left\{\begin{array}{c}
\text { Sandy limestones with some marl beds ; lower } \\
\text { limestone with vertical plant-markings } \\
\text { (Lower Estuarine Series) }
\end{array}\right.
\end{aligned}
$$

(About 12 feet of Inferior Oolite strata can be made out below.)

The faulted state of the bank prevents exact measurement of the series now assumed to be Fullonian. These beds had previously been classed with the Inferior Oolite. Notwithstanding the great care taken in making a practically vertical section, a series of Great Uolite beds was found at a much lower level than the Slate. The error was indicated in the Second Report, and the greater part of beds Nos. 18 to 26 has to be excised from the list.

The additions to our knowledge consist mainly in the discovery of the strata with vertical plant-markings (evidently the equivalent of the Lower Estuarine Series of the Nortbamptonshire Inferior Oolite), and in the particulars given of the thickness of the higher beds of the Inferior Oolite and the Fullonian strata. Fawler, two miles distant, has been supposed to mark the virtual disappearance of the Inferior Oolite. Sir Joseph Prestwich, however, had grouperl with the Inferior Oolite certain beds ( 14 feet 6 inches thick) which 


\section{Notices of Memoirs-A. C. Sercard-Lyginodendron.}

had been proved in the boring at Wytham, near Oxford $;^{1}$ and Mr. H. B. Woodward has classed with the Inferior Oolite Series 30 feet of strata proved in a boring at Witney. ${ }^{2}$ 'These correlations were inferential, but the facts now brought forward give them support.

VI.-A New Cyoad from the Isle of Portland. By A. C. Seward, M.A., F.G.S.

$\mathrm{D}^{\mathrm{R}}$ R. WOODWARD lately obtained an exceedingly fine specimen of a cycadean stem from the Purbeck Beds of Portland, which is now in the fossil plant gallery of the British Museum. The stem, which is probably the largest known, has a height of $1 \mathrm{~m} .18 .5 \mathrm{~cm}$., and measures $1 \mathrm{~m} .7 \mathrm{~cm}$. in girth at the broadest part. A striking feature of the specimen is the conical apical bud enclosed by tapered bud-scales, bearing numerous ramental outgrowths on the exposed surface. The surface of the stem presents the appearance of a prominent reticulum of projecting ridges, of which the meshes were uriginally occupied by the persistent petiole hases. The substance of the leaf-stalks has for the most part disappeared, while the interpetiolar ramental tissue has been mineralized and so preserved as a projecting framework. In structure the ramenta are practically identical with those of Bennettites, as described by Carruthers and other writers. The petiole bases also agree very closely with those of Bennettites, consisting of a mass of parenchymatous tissue traversed by numerous vascular bundles and secretory canals, with a distinct band of cork at the periphery. No trace of any inflorescence has been found. It is proposed to name the plant Cycadeoidea gigantea.

VII.-Note on a Large Specimen of Lyginodendron. By A. C. Seward, M.A., F.G.S.

TTHE specimens on which this description is based are in the 1 Botanical Department of the British Mnseum and in the recently acquired Williamson Collection. The block, from which several sections have been prepared, is a striking example of the preservation of the minute structure of a Coal-measure plant on a large scale; it consists of a mass of wood at least $6 \mathrm{~cm}$. thick in a radial direction, and a pith about $3 \mathrm{~cm}$. in diameter, but withont any trace of cortical tissue. Sections obtained from this block, and included in the Williamson Collection, were described at some length in the recently published memoir by Williamson and Scott on Lyginodendron and Heterangium. The examination of additional specimens has led to a somewhat fuller diagnosis of the structure and a more detailed comparison with Lyginodendron Oldhanium and other plants. The main mass of the wood possesses a structure practically identical with that of Lyginodendron Oldhamium and recent cycadean stems; internal to the centrifugally developed

1 Geol. Mag. 1876 , p. 238.

2 "Jurassic Rocks of Britain," vol. v, 1895, p. 42 
secondary wood there is a fairly complete and narrow ring of centripetally developed xylem. In the pith there are numerons secretory canals and nests of dark-coloured sclerous cells. No definite traces of priniary xylem like that of Lyginodendron Oldhamium have been detected. As a matter of convenience the specimen may be designated Lyginodendron robustum.

VIII.-Note on some Fossil Plants from Sodth Africa. By A. C. SEward, M.A., F.G.S.

I IHE author has recently had an opportunity, through the kindness of Mr. David Draper, F.G.S., of examining a collection of fossil plants from a locality a short distance south of Johannesburg. The collection forwarded to England by $\mathrm{Mr}$. Draper includes examples of Glossopteris, Vertebraria, and other genera, associated with specimens of Lepidophloios. The occurrence of Lepidodendrons in strata containing typical members of the Glossopteris flora is extremely important from the point of view of the geological and geographical distribution of fossil plants, and specially interesting in connection with a similar association lately recorded by Professor Zeiller in Brazilian plant-bearing beds. In South Africa, as in South America, we have evidence of the existence of a plant genus characteristic of the Upper Palæozoic flora of the northern hemisphere, in the same region with the Permo-Carboniferous Glossopteris flora.

IX.-Lifh-zones in the British Carboniferous Rocks.-Report of the Committee, consisting of J. E. MarR, F.R.S. (Chairman), E. J. Garwood, F.G.S. (Secretary), and A. H. Foord, F.G.S., appointed to study the Life-zones in the British Carboniferous Rocks. (Drawn up by J. E. Marr.)

J a paper read before the British Association at Ipswich in 1895, two of us called attention to the work of Dr. Waagen on the Upper Palæozoic rocks of the Salt Range, and gave reasons for supposing that the Carboniferous rocks of Britain might be divided into zones." In that paper it was suggested "that a committee be appointed to inquire into the possibility of dividing the Carboniferous rocks into zones, to call the attention of local observers to the desirability of collecting fossils with this view, and, if possible, to retain the services of eminent specialists to whom these fossils may be submitted." This committee was appointed, and the members thereof beg leave to submit their report.

The Committee believes that the following districts would furnish good results, and recommends that those whose names are appended to the various districts be asked to take charge of their particular districts and to endeavour to carry out therein the objects of the Committee-

1 See Rep. Brit. Assoc. 1895, p. 696. 
England and Wales: Northumberland and the Border, Professor G. A. Lebour; Northern part of Pennine Chain and adjoining regions, Messrs. Garwood and Marr; Southern part of ditto and adjoining regions, Mr. P. F. Kendall and Dr. Wheelton Hind; North Wales, Mr. G. H. Morton; South Wales, Mr. A. Strahan; Devon, etc., Mr. Howard Fox and Dr. G. J. Hinde.

Isle of Man: Mr. G. W. Lamplugh.

Scotland: Mr. B. N. Peach.

Ireland: Mr. A. H. Foord.

The Committee recommends that the following directions for working be conmunicated to the various workers :-

1. When possible, a typical measured section should be given of each locality examined, with notes of as many confirmatory sections as possible.

2. Any specimen not actually found in sitù to be labelled to that effect, with the exact conditions under which it was found noted.

3. All specimens should be labelled with the local name of the bed, giving as many additional details as possible, and in all cases the exact locality, which should further be noted on a large scale-map.

4. All specimens should be labelled when found.

5. So far as possible, workers are recommended to collect from one bed at a time, and to pack the specimens from each bed in a separate parcel before commencing to collect from another bed.

6. Attention should be paid to apparently identical forms separated by many feet or yards of deposit, as the forms may be mutations; large suites of such specimens should be collected; indeed-

7. As large a number of specimens as possible should be obtained of each species in every bed examined.

8. Absence of fossils in any bed should be noted whenever possible.

9. Attempts should be made to record the relative abundance of fossils, which may be roughly done by recording those which are very rare $(v, r)$, rare $(\boldsymbol{r}$.$) , common (c)$, and very common $\left(v, c_{.}\right)$.

10. In case of beds being obviously rich in micro-organisms, large pieces should be collected for future examination.

11. Considering the importance which cherts have assumed, it is very desirable to collect specimens of cherts.

Specimens may be kept by the discoverers or forwarded to the Secretary of the Committee (E. J. Garwood, Dryden Chambers, 119, Oxford Street, London, W.), on loan or for retention.

The Committee recommends that the names of those whom they have mentioned as likely to undertake the charge of districts be adiled to the Committee, and that the following palæontologists be asked to co-operate with the other members, and to identify such fissils as may be submitted to them, their names being also added (when not previously mentioned) to those of the Committee: Dr. G. J. Hinde (radiolaria and sponges), Professor H. A. Nicholson 
(corals), Mr. J. W. Kirkby (entomostraca), Dr. H. Woodward (other crustacea), Mr. F. A. Bather (echinoderms and brachiopods), Dr. Wheelton Hind and Mr. E. J. Garwood (lamellibranchs and gasteropods), Messrs. G. C. Crick and A. H. Foord (cephalopods), and Mr. R. Kidston (plants).

The Committee recommends that a grant be applied for, in order to pay for the services of collectors, who are to be under the direction of the Secretary of the Committee.

\section{X.-The Rippling of Sand by Water and by Wind. By Vaughan Cornish.}

DEGULAR ripple-mark is produced in various ways in rolling 14 sand. The billows formed by deposition of flying or floating sand are considered in another paper (Section E-Geography). The author distinguishes three principal kinds of rippled sand, viz. :

1. The Ripple-mark of Sea.

2. The Ripple-mark of Streams.

3. The Ripple-mark of Dunes.

In (1) symmetrical, knife-edged ridges are built up, owing, as is well known, to the complete reversal of the current at short intervals, which results in an effective co-operation of the direct current with the vortex formed in the lee of projections on the rough surface of the sand. This mechanism in the vertical plans raises the ridges, and, in plan, extends them laterally, so that the mottled surface of the initial stage is changed into long lines of parallel ridge and furrow.

If the direction of the waves changes, another set of ridges is formed, and this produces polygonal figures. These have an even number of sides, and the sides are arranged in opposing pairs. This serves to discriminate polygonal forms due to fossil ripplemark from Hitchcock's supposed fossil tadpole-nests.

2. The symmetrical, rounded, ripple-mark of the sandy bottom of a stream is formed by the alternate acceleration and retardation of current which occurs wherever the surface of the water is corrugated by a train of standing waves. This form has been called Ripple Drift. The ridges only travel when the whole train of water-waves travels; when the train of waves arises from a fixed obstacle the sand ridges are stationary.

3. The ripple-mark of dunes is produced-when sand-grains roll before the wind. These ripples are not symmetrical, but they preserve their sectional shape during their growth, the height and length increasing in the same proportion. They grow laterally in the same way as (1). They are produced by the steadiest natural wind, and even by a steady artificial blast, the resistance offered by the sand-grains being sufficient to produce in yielding air a periodic motion such as must be independently produced in water for the formation of the ripple-mark of sea or stream.

Flying-sand falling upon the surface of a sand-dune blurs the pattern of the ripples, hut if the shower be not too thick the grains are soun sorted into position as they roll. 